\title{
Role of glutathione in tolerance to arsenite in Salvinia molesta, an aquatic fern
}

\section{Adinan Alves da Silva ${ }^{*}$, Juraci Alves de Oliveira², Fernanda Vidal de Campos' ${ }^{1}$, Cleberson Ribeiro ${ }^{2}$ and Fernanda dos Santos Farnese}

Received: February 10, 2017

Accepted: June 26, 2017

\begin{abstract}
In many plant species, tolerance to toxic metals is highly dependent on glutathione, an essential metabolite for cellular detoxification. We evaluated the responses of glutathione metabolism to arsenite (As ${ }^{\text {III }}$ in Salvinia molesta, an aquatic fern that has unexplored phytoremediation potential. Plants were exposed to different As ${ }^{\text {III }}$ concentrations in nutrient solution for $24 \mathrm{~h}$. As ${ }^{\mathrm{III}}$ caused cell membrane damage to submerged leaves, indicating oxidative stress. There was an increase in the glutathione content and $\Upsilon$-glutamylcysteine synthetase enzyme activity in the submerged and floating leaves. The glutathione peroxidase and glutathione sulfotransferase enzymes also showed increased activity in both plant parts, whereas glutathione reductase only showed increased activity in the submerged leaves. These findings suggest an important role for glutathione in the protection of $S$. molesta against the toxic effects of As $s^{\text {III }}$, with more effective tolerance responses in the floating leaves.
\end{abstract}

Keywords: arsenic, glutathione, macrophytes, oxidative stress, phytoremediation

\section{Introduction}

Human populations are mainly exposed to arsenic (As) through consumption of contaminated water. Estimates suggest that between 150 and 200 million people are exposed to As concentrations above the $10 \mu \mathrm{g} / \mathrm{L}$, the maximum recommended by the World Health Organization (WHO) (Naujokas et al. 2013). India and Bangladesh are the most affected countries in the world, where prolonged ingestion of As-contaminated water has been the cause of many health problems, including skin diseases, respiratory diseases, and cancer (Chakraborti et al. 2016a; b).

In aquatic environments, the inorganic As forms predominate, occurring mainly as arsenate $\left(\mathrm{As}^{\mathrm{V}}\right)$ or arsenite $\left(\mathrm{As}{ }^{\mathrm{III}}\right)$. Arsenite is the most toxic form and it is more commonly found in naturally contaminated groundwater sources (Zheng et al. 2017). The precipitation, ion exchange, adsorption, and membrane-based filtrations are physicochemical technologies that are available to remove As from water. However, they all have environmental and economic losses, as well as being more efficient for $\mathrm{As}^{\mathrm{V}}$ than As ${ }^{\text {III }}$ (Nicomel et al. 2016).

An alternative method of removing As from the ecosystems is via plant uptake and accumulation of the pollutant in their roots and/or leaves. This technique is known as phytoremediation and presents some advantages, such as lower implementation cost, low environmental impact and applicability in vast contaminated areas (Bernardino et al. 2016). Several macrophyte species have shown potential for As phytoremediation from contaminated water, including

\footnotetext{
${ }^{1}$ Departamento de Biologia Vegetal, Universidade Federal de Viçosa, Av. Peter Henry Rolfs, s/n, 36570-000, Viçosa, MG, Brazil

${ }^{2}$ Departamento de Biologia Geral, Universidade Federal de Viçosa, Av. Peter Henry Rolfs, s/n, 36570-000, Viçosa, MG, Brazil

${ }^{3}$ Laboratório de Ecofisiologia Vegetal, Instituto Federal de Educação, Ciência e Tecnologia Goiano-Campus Rio Verde, 75901-970, Rio Verde, GO, Brazil

*Corresponding author: adinan.alves64@gmail.com
} 


\section{Adinan Alves da Silva, Juraci Alves de Oliveira, Fernanda Vidal de Campos, Cleberson Ribeiro and Fernanda dos Santos Farnese}

Eichhornia crassipes (Alvarado et al. 2008), Pistia stratiotes (Farnese et al. 2013), and Lemna gibba (Leão et al. 2014).

The As ${ }^{\text {III }}$ absorbed by the plant affects physiological processes such as photosynthesis and growth, besides promoting cell damage (Farooq et al. 2016). Despite being a non-redox metalloid, it is known that $\mathrm{As}^{\mathrm{III}}$ causes oxidative stress by increasing the generation of reactive oxygen species (ROS). This response is considered to be one of the most evident symptoms of As toxicity in plants (Zhao et al. 2010; Sharma et al. 2012).

Arsenite also features a high affinity for protein sulfhydryl groups and binds to transcription factors, signal transduction proteins, proteolytic and structural proteins, and metabolic and regulatory enzymes. This binding changes the structure and activity of these components in the plant cell (Finnegan \& Chen 2012). For example, the enzymatic complex pyruvate dehydrogenase is an important cellular target that is inhibited by As ${ }^{\text {III }}$ (Bergquist et al. 2009).

An essential mechanism for As tolerance in plants involves the complexes formed between the metalloid and rich SH-group compounds, especially the reduced glutathione molecule (GSH). The As-GSH complexes can be safely stored in vacuoles, to prevent cellular damage (Seth et al. 2012). Moreover, GSH is a key player in oxidative stress avoidance, by acting as a cofactor for antioxidant enzymes, directly scavenging ROS, or participating in the ascorbate-glutathione cycle, which is an essential pathway for maintenance of non-toxic levels of hydrogen peroxide in plant cells (Hossain et al. 2012; Zagorchev et al. 2013; Singh et al. 2015).

Some floating ferns of the Salvinia genus (Salvinia natans, Salvinia minima, and Salvinia molesta) have already shown the ability to absorb and tolerate toxic metals, including $\mathrm{As}{ }^{\mathrm{V}}$ (Rahman et al. 2008; Estrella-Gómez et al. 2012; Hariyady et al. 2013). However, limited information is available about

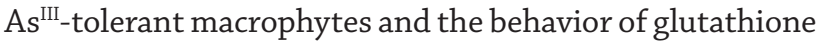
metabolism in these species.

To evaluate the capacity of S. molesta to As ${ }^{I I I}$ phytoextraction and potential to tolerate high As ${ }^{\text {III }}$ concentrations, we exposed the plants to the pollutant and studied the antioxidative functions of glutathione under these conditions. We tested the hypothesis that S. molesta is able to tolerate $\mathrm{As}^{\mathrm{III}}$ and this capacity is related to increases in GSH metabolism.

\section{Materials and methods}

\section{Plant material and treatment conditions}

Salvinia molesta D. S. Mitchell plants were collected in an artificial lake with an area of approximately $30 \mathrm{~m}^{2}$ and 60 $\mathrm{cm}$ in height, located in the Botanic Garden of the Federal University of Viçosa ( $\left.20^{\circ} 45^{\prime} 24^{\prime \prime S} 42^{\circ} 52^{\prime} 23^{\prime \prime} W\right)$. In this lake several species of aquatic plants are cultivated, including S. molesta. The water supplying the lake comes from the municipal water supply network.
Salvinia molesta is a floating aquatic fern that is native to southeastern Brazil. The plants are born from a rhizome and grow attached to it. From each node in this rhizome, two floating leaves originate and a set of modified submerged leaves constitutes a plant. The two leaf groups differ in their morphology. Floating leaves are green, oblong-shaped, and covered by papillae and hairs that repel water, while the submerged leaves are brown, long, and filiform, and present as numerous segments densely covered with hairs. These hairs are multicellular and have the ability to absorb water and nutrients, acting as a root. However, true roots are absent (Miranda \& Schwartsburd 2016).

The plants were acclimatized for 7 days in a growth chamber in diluted Clark nutrient solution (1/4 strength) (Clark 1975) at $\mathrm{pH} 6.5$, with a controlled temperature ( $25 \pm$ $\left.2^{\circ} \mathrm{C}\right)$ and irradiance $\left(250 \mu \mathrm{mol} \mathrm{m}^{-2} \mathrm{~s}^{-1}\right)$, and with a 16-h light photoperiod. Plants with similar sizes were then exposed to the following treatments: control (Clark nutrient solution $1 / 4$ strength) and three As concentrations (5, 10 and $20 \mu \mathrm{M})$, which were provided in arsenite sodium form $\left(\mathrm{NaAsO}_{2}\right)$ in a nutrient solution for 24 hours, under the same conditions described above.

At the end of exposure, plants were harvested, and floating leaves and submerged leaves were separated, washed in deionized water and immediately analyzed or stored at $-80^{\circ} \mathrm{C}$. Experiments were set up with three replicates, each consisting of $4 \mathrm{~g}$ of fresh weight plants in glass pots with $0.5 \mathrm{~L}$ of solution.

\section{Determination of arsenic concentration}

After treatment, floating and submerged leaves were dried in a conventional oven at $80^{\circ} \mathrm{C}$, until a constant dry mass was obtained. The oven-dried plant materials were finely ground in a steel electric grinder and $0.1 \mathrm{~g}$ was digested in a nitric-perchloric acid mixture (2:1). A blank sample was also digested (Marin et al. 1993). The As concentration was determined through inductively coupled plasma atomic emission spectroscopy (ICP-AES) (Optima 3300 DV, PerkinElmer, Norwalk, CT, USA). The accuracy of the analytical technique was verified by analyzing the certified reference material (Tomato leaves - NIST, SRM 1573a, Gaithersburg, MD, USA).

\section{Lipid peroxidation}

Lipid peroxidation was determined by estimating the malondialdehyde (MDA) content, using the method described by Heath \& Packer (1968), with modifications. An approximately $80 \mathrm{mg}$ sample of floating and submerged leaves was homogenized in $2 \mathrm{~mL} 0.1 \%$ trichloroacetic acid (TCA) and centrifuged at 10,000 $\mathrm{g}$ for $20 \mathrm{~min}$. Then, $1 \mathrm{~mL}$ of $0.5 \%$ thiobarbituric acid in $20 \%$ TCA was added to a 0.5 $\mathrm{mL}$ supernatant aliquot. The reaction mixture was heated to $95^{\circ} \mathrm{C}$ for $30 \mathrm{~min}$ and then cooled quickly in an ice bath. 


\section{Role of glutathione in tolerance to arsenite in Salvinia molesta, an aquatic fern}

After an additional centrifugation at $10,000 \mathrm{~g}$ for $15 \mathrm{~min}$, the absorbance of the supernatant was taken at 532 and $600 \mathrm{~nm}$. The lipid peroxidation level was calculated using the molar extinction coefficient $155 \mathrm{mM}^{-1} \mathrm{~cm}^{-1}$ (Hodges et al. 1999) and results were expressed in $\mathrm{nmol} \mathrm{MDA} \mathrm{g}{ }^{-1}$ fresh weight.

\section{Total glutathione content (GSH + GSSG)}

The total glutathione content (reduced (GSH) + oxidized (GSSG)) was determined according to the method described by Griffith (1980). Approximately $250 \mathrm{mg}$ of fresh mass samples were homogenized in $2 \mathrm{~mL}$ of extraction medium, consisting of $0.1 \mathrm{M} \mathrm{HCl}$ containing $1 \mathrm{mM}$ ethylenediaminetetraacetic acid (EDTA). The extract was centrifuged for 15 minutes at $12,000 \mathrm{~g}$ and $4^{\circ} \mathrm{C}$. Aliquots with $200 \mu \mathrm{L}$ of the supernatant were added in a reaction mix, containing $200 \mu \mathrm{L}$ of $125 \mu \mathrm{M}$ sodium phosphate buffer with disodium salt of $6.3 \mathrm{mM}$ EDTA at $\mathrm{pH} 7.5,500 \mu \mathrm{L} 0.3$ $\mathrm{mM}$ nicotinamide adenine dinucleotide phosphate reduced (NADPH), and $100 \mu \mathrm{L} 6.0 \mathrm{mM}$ 5,5'-Dithiobis (2-nitrobenzoic acid) (DTNB). The absorbance was measured at $412 \mathrm{~nm}$ for 1 minute, after addition of 0.5 units of reductase glutathione enzyme. The total glutathione content was determined using a calibration curve and results were expressed in nmol glutathione $\mathrm{g}^{-1}$ fresh weight.

\section{$\Upsilon$-glutamylcysteine synthetase activity $\Upsilon$-ECS, EC 6.3.2.2)}

$\Upsilon$-ECS activity was evaluated according to Rüegsegger \& Brunold (1992), using approximately $250 \mathrm{mg}$ of plant material. Samples were homogenized in $2.0 \mathrm{~mL}$ of the extraction medium, consisting of $0.10 \mathrm{M}$ Tris- $\mathrm{HCl}$ buffer and $5.0 \mathrm{mM}$ EDTA at $\mathrm{pH}$ 8.0. The enzyme activity was determined by adding $100 \mu \mathrm{L}$ of crude enzyme extract to $0.9 \mathrm{~mL}$ of a reaction medium containing $10 \mu \mathrm{M}$ sodium glutamate, $10 \mu \mathrm{M}$ L-aminobutyrate, $2.0 \mathrm{mM}$ EDTA, $0.2 \mathrm{mg}$ bovine serum albumin (BSA), $20 \mu \mathrm{M}$ magnesium chloride $\left(\mathrm{MgCl}_{2}\right), 5.0 \mu \mathrm{M}$ disodium salt ATP, and $100 \mathrm{mM}$ Tris- $\mathrm{HCl}$ buffer at $\mathrm{pH}$ 8.2. The mixture was incubated at $37^{\circ} \mathrm{C}$ for 30 minutes and the reaction was stopped by adding 100 $\mu \mathrm{L} 50 \% \mathrm{TCA}$. Then, the mixture was centrifuged at 10.000 $g$ for $10 \mathrm{~min}$, and the inorganic phosphate content in the supernatant was determined at $720 \mathrm{~nm}$ using the phosphomolybdate method (Lindeman 1958).

\section{Glutathione reductase activity (GR, EC 1.8.1.7)}

Approximately $250 \mathrm{mg}$ of fresh mass samples were homogenized in $2 \mathrm{~mL}$ of extraction medium consisting of 0.1 M potassium phosphate buffer at $\mathrm{pH}$ 7.0, 1.0 mM EDTA, 2.0 $\mathrm{mM}$ dithiothreitol (DTT), $1.0 \mathrm{mM}$ phenylmethanesulfonyl fluoride (PMSF), and $1 \%$ polyvinylpolypyrrolidone (PVPP). The extract was centrifuged at $12,000 \mathrm{~g}$ for $15 \mathrm{~min}$ at $4^{\circ} \mathrm{C}$.
The GR activity was determined by adding $100 \mu \mathrm{L}$ of crude enzyme extract to $0.9 \mathrm{ml}$ of a reaction medium consisting of $0.10 \mathrm{M}$ potassium phosphate bufferpH 7.5, 1.0 mM EDTA, $1.0 \mathrm{mM}$ oxidized glutathione (GSSG), and $0.10 \mathrm{mM} \mathrm{NADPH}$ in $0.5 \mathrm{mM}$ Tris-HCl buffer at pH 7.5 (Carlberg \& Mannervik 1985). The decrease in absorbance was measured during the first minute of the reaction and the enzyme activity was calculated using the molar extinction coefficient $6.22 \mathrm{mM}^{-1}$ $\mathrm{cm}^{-1}$ (Foyer \& Halliwell 1976). The results were expressed in nmol NADPH oxidized $\mathrm{min}^{-1} \mathrm{~g}^{-1}$ fresh weight.

\section{Glutathione peroxidase activity (GPX, EC 1.11.1.9)}

To analyze the activity of GPX, approximately $250 \mathrm{mg}$ of fresh mass samples were homogenized in an extraction medium, consisting of $0.1 \mathrm{M}$ Tris- $\mathrm{HCl}$ buffer at $\mathrm{pH}$ 7.5, 1.0 $\mathrm{mM}$ EDTA, and $10 \mathrm{mM} \mathrm{MgCl}_{2}$. The enzyme activity was measured by adding $100 \mu \mathrm{L}$ of crude enzyme extract to 0.9 $\mathrm{mL}$ of a reaction medium, consisting of $50 \mathrm{mM}$ potassium phosphate buffer at $\mathrm{pH}$ 7.0, 1.0 mM EDTA sodium chloride, $1.0 \mathrm{mM}$ reduced glutathione (GSH), $0.2 \mathrm{mM} \mathrm{NADPH}, 0.25$ $\mathrm{mM}$ hydrogen peroxide $\left(\mathrm{H}_{2} \mathrm{O}_{2}\right)$, and 1 unit of glutathione reductase enzyme (Nagalakshmi \& Prasad 2001). The absorbance was measured at $340 \mathrm{~nm}$ during the first minute of the reaction and the GPX activity was calculated using the molar extinction coefficient of $6.22 \mathrm{mM}^{-1} \mathrm{~cm}^{-1}$ (Anderson \& Davis 2004). The results were expressed in nmol NADPH oxidized $\min ^{-1} \mathrm{~g}^{-1}$ fresh weight.

\section{Glutathione-S-transferase activity (GST, EC 2.5.1.18)}

The GST activity was determined according to the methodology proposed by Habig et al. (1974) and Habig \& Jakoby (1981), using approximately $250 \mathrm{mg}$ of fresh mass. Samples were homogenized with $2.0 \mathrm{~mL}$ of an extraction medium, with $0.2 \mathrm{M}$ Tris- $\mathrm{HCl}$ buffer at $\mathrm{pH} 7.8,1.0 \mathrm{mM}$ EDTA, $1.0 \mathrm{mM}$ DTT, $0.10 \mathrm{mM}$ PMSF, and $5 \%$ PVPP. GST activity was determined following addition of $0.1 \mathrm{~mL}$ of the crude enzyme extract to $0.9 \mathrm{~mL}$ of a reaction medium consisting of $0.20 \mathrm{M}$ potassium phosphate buffer at $\mathrm{pH}$ 6.5, $20 \mathrm{mM} \mathrm{GSH}$, and 0.10 M 1-chloro-2,4-dinitrobenzene (CDNB). The absorbance was measured at $340 \mathrm{~nm}$ and the enzyme activity was calculated using the molar extinction coefficient $9.6 \mathrm{mM}^{-1} \mathrm{~cm}^{-1}$ and expressed in $\mathrm{nmol} \mathrm{min}{ }^{-1} \mathrm{~g}^{-1}$ fresh weight.

\section{Statistical analysis}

The experiment was performed using a randomized design. Data were analyzed using a two-way analysis of variance (ANOVA) followed by a means comparison using Tukey's test. $P<0.05$ was considered to be significant. The statistical analyses were performed using the statistical software $\mathrm{SAEG}^{\circ} 9.1$ (Universidade Federal de Viçosa, Viçosa, Brazil). 


\section{Adinan Alves da Silva, Juraci Alves de Oliveira, Fernanda Vidal de Campos, Cleberson Ribeiro and Fernanda dos Santos Farnese}

\section{Results}

\section{As accumulation}

As accumulation in the plants (absorbed and adsorbed) increased both in the submerged leaves and floating leaves as the $\mathrm{As}{ }^{\mathrm{III}}$ concentration increased in the nutrient solution. However, the As content was significantly higher in the submerged leaves compared with the floating leaves in all As ${ }^{\mathrm{III}}$ treatments (Tab. 1).

Table 1. Arsenic concentration $\left(\mu \mathrm{g} \mathrm{g}^{-1} \mathrm{DW}\right)$ on S. molesta floating leaves and submerged leaves after 24 hours of $A s^{\text {III }}$ exposure. Values are means of three replicates $(n=3) \pm$ SD. Means followed by different capital letters for the same column and small letters for the same row, show significant difference at $P<0.05$, according to Tukey test. nd*- non detected.

\begin{tabular}{|c|c|c|}
\hline As $^{\text {III }}(\mu \mathrm{M})$ & Floating leaves & Submerged leaves \\
\hline 0 & nd $^{*}$ & nd $^{*}$ \\
\hline 5 & $8.72 \pm 1.15 \mathrm{Cb}$ & $45.75 \pm 2.21 \mathrm{Ca}$ \\
\hline 10 & $13.91 \pm 1.75 \mathrm{Bb}$ & $91.42 \pm 2.31 \mathrm{Ba}$ \\
\hline 20 & $25.40 \pm 0.66 \mathrm{Ab}$ & $144.21 \pm 17.11 \mathrm{Aa}$ \\
\hline
\end{tabular}

\section{Integrity of cell membranes}

The concentration of malondialdehyde (MDA) in the floating leaves only differs from control in plants that were exposed to $10 \mu \mathrm{M} A s^{\mathrm{III}}$, while in submerged leaves, there was an increase in MDA for all As ${ }^{\mathrm{III}}$ treatments (Fig. 1).

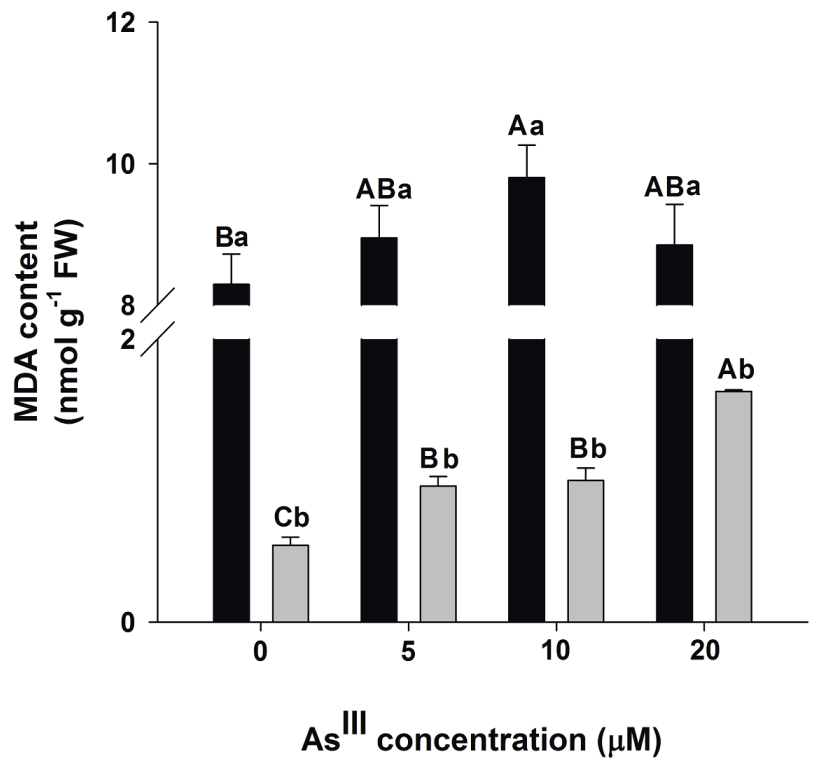

Figure 1. Malondialdehyde concentration on floating leaves (black bar) and submerged leaves (grey bar). Bars represent standard deviation $(n=3)$. Means followed by different capital letters for the same plant part and small letters between plant parts, show significant difference at $P<0.05$, according to Tukey test.

\section{Total glutathione content}

The total glutathione content increased on in the floating and submerged leaves in all As ${ }^{\mathrm{III}}$ treatments. In plants exposed to higher As ${ }^{\mathrm{III}}$ concentrations, the content of glutathione in the floating leaves was approximately two times higher than that observed in control, while in the submerged leaves, the GSH concentration was more than three times higher than control. Regardless of the treatment, the total glutathione content was always higher in floating leaves compared with submerged leaves (Fig. 2).

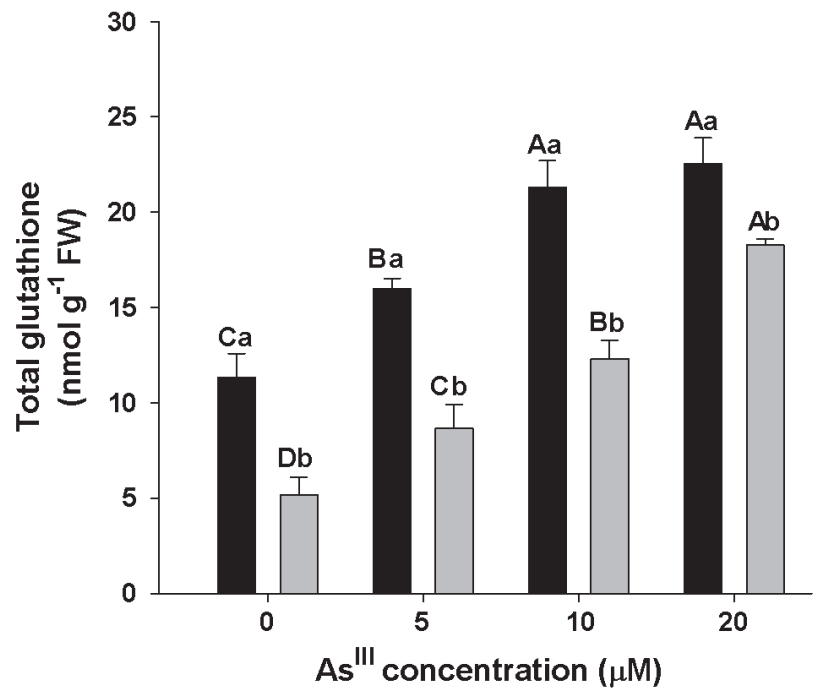

Figure 2. Content of total glutathione on floating leaves (black bar) and submerged leaves (grey bar). Bars represent standard deviation $(n=3)$. Means followed by different capital letters for the same plant part and small letters between plant parts, show significant difference at $P<0.05$, according to Tukey test.

\section{Glutathione metabolism enzymes}

The activity of glutathione metabolism enzymes showed distinct responses, which were influenced by the plant part analyzed (Fig. 3).

The $\Upsilon$-ECS activity in floating leaves only increased in plants exposed to higher $\mathrm{As}^{\mathrm{III}}$ concentration. In the submerged leaves, there was an increase in all As treatments, with the highest enzyme activity observed in $20 \mu \mathrm{M} \mathrm{As}{ }^{\mathrm{III}}$, but there was no remarkable difference between 5 and $10 \mu \mathrm{M} \mathrm{As} s^{\mathrm{III}}$. In the $10 \mu \mathrm{M} A s^{\mathrm{III}}$ treatment, there was no difference in enzyme activity between the floating leaves and submerged leaves (Fig. 3A).

The As ${ }^{\text {III }}$ concentration did not affect GR activity in the floating leaves. However, the enzyme activity in submerged leaves increased in all As ${ }^{\mathrm{III}}$ treatments. GR activity did not differ between the evaluated plant parts exposed to $20 \mu \mathrm{M}$ $\mathrm{As}^{\mathrm{III}}$, but it was higher in floating leaves in all the other treatments (Fig. 3B). 


\section{Role of glutathione in tolerance to arsenite in Salvinia molesta, an aquatic fern}
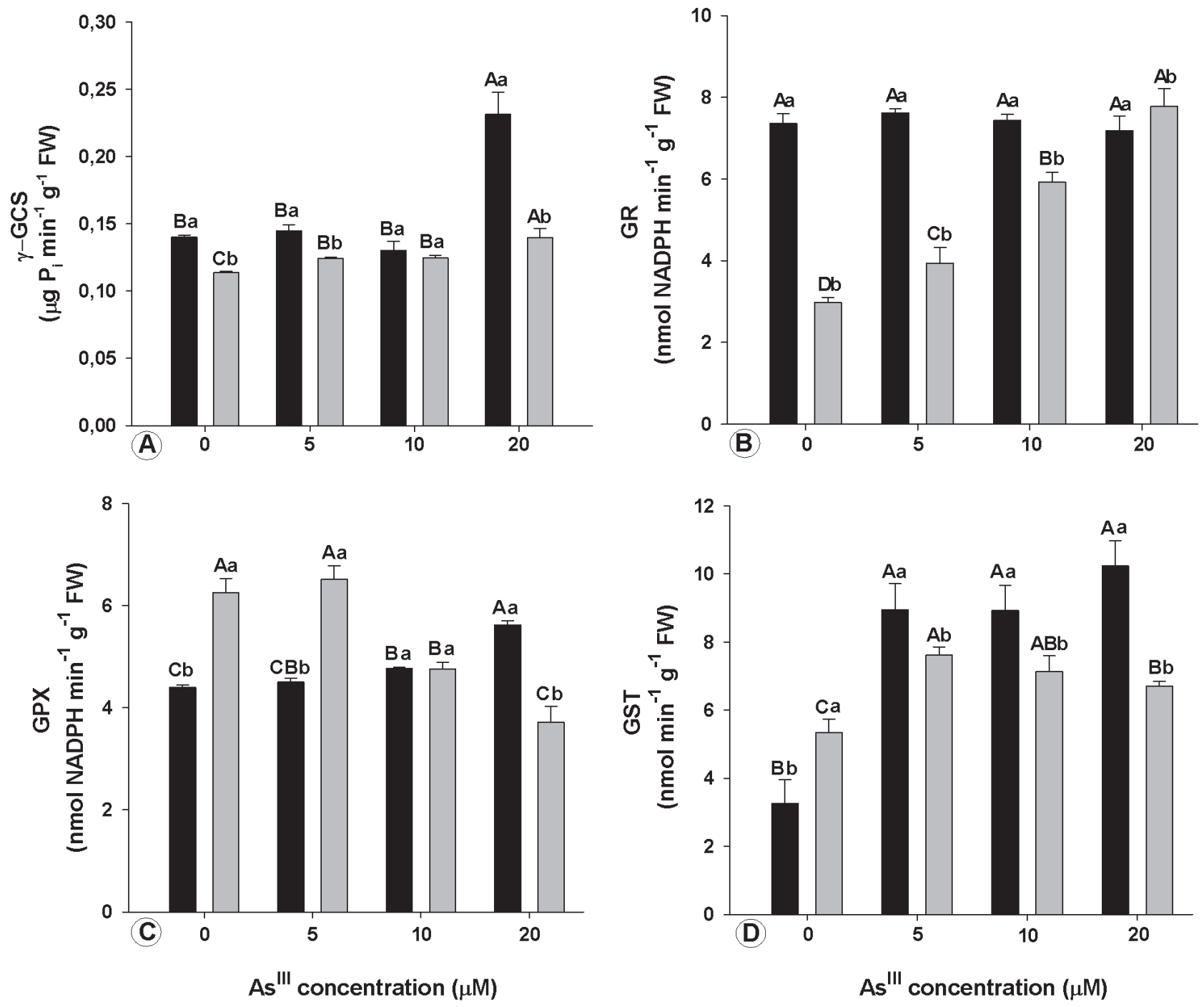

Figure 3. Activity of enzymes: -ECS (a), GR (b), GPX (c) and GST (d) on floating leaves (black bar) and submerged leaves (grey bar). Bars represent standard deviation $(n=3)$. Means followed by different capital letters for the same plant part and small letters between plant parts, show significant difference at $P<0.05$, according to Tukey test.

The GPX activity in S. molesta floating leaves showed increases at 10 and $20 \mu \mathrm{M} A s^{\mathrm{III}}$ concentrations, while in the submerged leaves, there was a noticeable decrease in GPX activity with these same treatments. Comparing the enzyme activities between plant parts, there was increased GPX activity in the submerged leaves at lower $\mathrm{As}{ }^{\mathrm{III}}$ concentrations and higher activity in floating leaves at $20 \mu \mathrm{M} \mathrm{As}{ }^{\mathrm{III}}$ (Fig. 3C).

Exposure to As ${ }^{\text {III }}$ induced increases in GST activity in floating leaves and submerged leaves. We observed that in submerged leaves, the enzyme activity decreased at the highest As ${ }^{\text {III }}$ concentration compared to the other As $s^{\text {III }}$ treatments (Fig. 3D).

\section{Discussion}

Salvinia molesta was able to absorb and/or adsorb substantial amounts of As in short period of exposure to the treatments. Aquatic plants can help to reduce heavy metals in the environment in an active way through As absorption and passively by As adsorption to the surface of their roots. The adsorption promotes pollutant phytostabilization by reducing its mobility and migration (Rai \& Tripathi 2011; Dixit et al. 2015).

Once the whole plant is removed from the water, the absorption and adsorption process can contribute to environmental pollutant removal. Thus, $S$. molesta is an interesting plant in the phytoremediation processes, and a higher As content was observed in its submerged leaves compared with macrophytes commonly used in As phytoremediation such as Hydrilla verticillata (Srivastava et al. 2007) and Ceratophyllum demersum (Khang et al. 2012), under similar experimental conditions. Moreover, the As content in S. molesta increased in all treatments, indicating no saturation of 


\section{Adinan Alves da Silva, Juraci Alves de Oliveira, Fernanda Vidal de Campos, Cleberson Ribeiro and Fernanda dos Santos Farnese}

As removal capacity by the plant under the evaluated conditions (Zhao et al. 2009).

The higher accumulation of As in $S$. molesta submerged leaves, which plays the role of roots, follows a trend usually observed in macrophytes (Zhao et al. 2009; Farnese et al. 2013) and acts as a defense strategy (Rahman \& Hasegawa 2011). A key mechanism involved in the $A s^{I I I}$ retention in root cells is the complexation with phytochelatins (PCs), or $\mathrm{GSH}$. These complexes are sequestered in vacuoles, which reduces As transportation to the shoots and protects the photosynthetic tissues (Liu et al. 2010).

Several studies have shown that As accumulation promotes an increase in ROS generation in plants (Talukdar 2013; Upadhyaya et al. 2014; Tripathi et al. 2015). ROS are reactive molecules that are capable of damaging cell biomolecules, and whose preferred targets are biological membranes. Lipid peroxidation is a common injury resulting from As stress and MDA is an oxidative stress biochemical marker in plants (Sharma 2012; Sytar et al. 2013). Therefore, we can say that $\mathrm{As}{ }^{\mathrm{III}}$ that accumulated in the S. molesta floating and submerged leaves promoted oxidative stress and cell damage in plants. Although cellular damage occurred only $24 \mathrm{~h}$ after exposure to treatments, the As ${ }^{\text {III }}$ concentrations used in this test are much higher than those naturally found in regions where there are water sources with high levels of As contamination (Chakraborti et al. 2016c).

As exposure can induce glutathione synthesis in plants, which was verified in S. molesta. Increases in glutathione levels were also related to the As response in other macrophytes, such as C. demersum (Mishra et al. 2008) and Wolffia globosa (Zhang et al. 2012). Glutathione is directly linked to the plants' ability to tolerate stress caused by toxic metals and it may be used primarily as a substrate for PC synthesis and to promote acclimatization and survival (Hernández et al. 2015).

GSH synthesis occurs mainly in the cytosol, chloroplasts, and mitochondria, and $\Upsilon$-ECS is the first enzyme involved in this process (Noctor et al. 2012). Increases in $\Upsilon$-ECS activity in submerged leaves sustained the increase in total glutathione content in S. molesta. Enhanced GSH synthesis enzyme activity is an important tolerance response to As stress to meet the higher demand for this metabolite in cellular defense antioxidant mechanisms (Hernández et al. 2015).

The increase in the GSH content of floating leaves in all As treatments, despite an increase in $\Upsilon$-ECS activity only at the highest concentration of the pollutant may have resulted from transport of glutathione synthesized in the submerged leaves to the floating leaves. Indeed, GSH can be transported over long distances through the phloem, for example, between root and shoot, within a few hours (Tausz et al. 2004; Li et al. 2006; Gigolashvili \& Kopriva 2014).

Glutathione acts as a cellular antioxidant when in its reduced state. Therefore, GR enzyme activity, which converts oxidized glutathione (GSSG) to reduced glutathione (GSH), plays a key role in the defense system against oxidative stress (Sytar et al. 2013). The stimulus for GR activity in the presence of As is a defense mechanism reported for different plant species (Srivastava et al. 2005; Singh et al. 2007; Shri et al. 2009), according to observations in the $S$. molesta submerged leaves. In the floating leaves, other antioxidant mechanisms may have been activated beyond the GSH. Scavenging ROS enzymes, such as superoxide dismutase (SOD) and catalase may be upregulated by As ${ }^{\text {III }}$ (Mishra et al. 2011). In addition, there is an alternative possible way to convert GSSG back to GSH through Class III peroxidases, a group of enzymes that are unique to plants (Liu et al. 2015).

The GSH is the substrate used by the enzymes GPX and GST to the removal of organic radicals and ROS (Meyer \& Hell 2005; Chi et al. 2011). GPX is considered to be a biomarker for heavy metal toxicity and an intrinsic defense mechanism against As in hyperaccumulating plants (Radotic et al. 2000; Srivastava et al. 2005). The GPX showed participation in antioxidant defenses in the S. molesta floating leaves. Similar results have been observed in Lemna gibba subjected to $\mathrm{As}^{\mathrm{V}}$ (Leão et al. 2014) and rice seedlings treated with $\mathrm{As} \mathrm{III}^{\mathrm{III}}$ (Mishra et al. 2011). Conversely, decreases in submerged leaves and may have contributed to further cellular damage in these organs. As ${ }^{\text {III }}$ has the ability to inhibit the activity of various enzymes (Shen et al. 2013) and GPX is considered to be As-sensitive (Chouchane \& Snow 2001).

The increase in GST activity indicates that the complex formation between GSH and As is an important defense mechanism in S. molesta, especially in floating leaves. GSTs are enzymes that are capable of catalyzing xenobiotic complexation with GSH, making the pollutant less reactive in the intracellular environment. High GST activity can be considered to be a biomarker of As tolerance in plants (Bianucci et al. 2017). Although submerged leaves have experienced increases in GST activity, the arsenic amount in their tissues may have generated a stress that exceeded their tolerance ability.

The present results suggest that GSH confers tolerance to As ${ }^{\text {III }}$ in $S$. molesta plants. The floating leaves showed a more efficient defense against oxidative damage. When in direct contact with the plants, toxic metals can be immediately retained and detoxified in the roots, mainly using phytochelatins at the expense of glutathione. This may lead to a delay in the response to the metal by the aerial part of the plant. In addition, the change in the ratio between reduced and oxidized glutathione (GSH:GSSG) can generate a redox signal, and once it is perceived by the aerial part, it allows more time for the activation of defense mechanisms against stress (Jozefczak et al. 2014). The floating leaves also had lower As accumulation, as well as a high glutathione content and action of the detoxification enzymes GPX and GST.

Despite the clear role of glutathione metabolism in submerged leaves, such as increasing the GSH concentrations 


\section{Role of glutathione in tolerance to arsenite in Salvinia molesta, an aquatic fern}

and GR and GST activities, the large As ${ }^{\text {III }}$ accumulation and its high toxicity promoted greater cellular damage in this part of the plant. Submerged leaves accumulated between 5 and 7 times more As than floating leaves.

To draw conclusions that are more reliable about the $A s^{\text {III }}$ tolerance level in S. molesta and validate their use for As phytoremediation, a long-term study with other As ${ }^{\text {III }}$ concentrations are required. Finally, this study reinforces the relevant role of glutathione in plant tolerance to $\mathrm{As}^{\mathrm{III}}$ and provides a basis for genetic breeding for toxic metal phytoremediation.

\section{Acknowledgements}

The authors thank the Coordenação de Aperfeiçoamento de Pessoal de Nível Superior (CAPES), the Fundação de Amparo à Pesquisa do Estado de Minas Gerais (FAPEMIG), the Conselho Nacional de Desenvolvimento Científico e Tecnológico (CNPq) and the Federal University of Viçosa for financial support.

\section{References}

Alvarado S, Guédez M, Lué-Merú MP, et al. 2008. Arsenic removal from waters by bioremediation with the aquatic plants water hyacinth (Eichhornia crassipes) and lesser duckweed (Lemna minor). Bioresource Technology 99: 8436-8440.

Anderson JV, Davis DG. 2004. Abiotic stress alters transcript profiles and activity of glutathione S-transferase, glutathione peroxidase, and glutathione reductase in Euphorbia esula. Physiologia Plantarum 120: 421-433.

Bernardino CAR, Mahler CF, Preussler KH, Novo LAB. 2016. State of the art of phytoremediation in Brazil-review and perspectives. Water Air and Soil Pollution 227: 272.

Bergquist ER, Fischer RJ, Sugden KD, Martin BD. 2009. Inhibition by methylated organo-arsenicals of the respiratory 2-oxo-acid dehydrogenases. Journal of Organometalic Chemistry 694: 973-980.

Bianucci E, Furlan A, Tordable MC, Hernández L, Carpena-Ruiz RO, Castro S. 2017. Antioxidant responses of peanut roots exposed to realistic groundwater doses of arsenate: Identification of glutathione S-transferase as a suitable biomarker for metalloid toxicity. Chemosphere 181: 551-561.

Carlberg I, Mannervik B. 1985. Glutathione reductase. Methods in Enzymology 113: 484-495

Chakraborti D, Rahman MM, Ahamed S, Dutta RN, Pati S, Mukherjee SC. 2016a. Arsenic contamination of groundwater and its induced health effects in Shahpur block, Bhojpur district, Bihar state, India: risk evaluation. Environmental Science and Pollution Reseach 23: 9492-9504.

Chakraborti D, Rahman MM, Ahmed S, Dutta RN, Pati S, Mukherjee SC. 2016b. Arsenic groundwater contamination and its health effects in Patna district (capital of Bihar) in the middle Ganga plain, India. Chemosphere 152: 520-529.

Chakraborti D, Rahmana MM, Chatterjeea A, et al. 2016c. Fate of over 480 million inhabitants living in arsenic and fluoride endemic Indian districts: Magnitude, health, socio-economic effects and mitigation approaches. Journal of Trace Elements in Medicine and Biology 38: 33-45.

Chi Y, Cheng Y, Vanitha J, et al. 2011. Expansion mechanisms and functional divergence of the glutathione $S$-transferase family in Sorghum and other higher plants. DNA Research 18: 1-16.
Chouchane S, Snow ET. 2001. In vitro effect of arsenical compounds on glutathione-related enzymes. Chemical Research in Toxicology 14: 517-22.

Clark RB. 1975. Characterization of phosphatase of intact maize roots. Journal of Agricultural and Food Chemistry 23: 458-460.

Dixit R, Malaviya WDD, Pandiyan K, et al. 2017. Bioremediation of heavy metals from soil and aquatic environment: an overview of principles and criteria of fundamental processes. Sustainability 7: 2189-2212.

Estrella-Gómez NE, Sauri-Duch E, Zapata-Pérez O, Santamaría JM. 2012 Glutathione plays a role in protecting leaves of Salvinia minima from $\mathrm{Pb}^{2+}$ damage associated with changes in the expression of SmGS genes and increased activity of GS. Environmental and Experimental Botany 75: 188-194.

Farnese FS, Oliveira JA, Gusman GS, et al. 2013. Plant responses to arsenic: the role of nitric oxide. Water Air and Soil Pollution 224:1660.

Farooq MA, Gill RA, Ali B, et al. 2016. Subcellular distribution, modulation of antioxidant and stress related genes response to arsenic in Brassica napus. Ecotoxicology 25: 350-366.

Finnegan PM, Chen W. 2012. Arsenic toxicity: the effects on plant metabolism. Frontiers in Physiology 3: 182. doi: 10.3389/ fphys.2012.00182.

Foyer CH, Halliwell B 1976. The presence of glutathione and glutathione reductase in chloroplasts: a proposed role in ascorbic acid metabolism. Planta 133: 21-25.

Gigolashvili T, Kopriva S. 2014. Transporters in plant sulfur metabolism. Frontiers in Plant Science 5: 442. doi: 10.3389/ fpls.2014.00442.

Griffith OW. 1980. Determination of glutathione and glutathione disulfide using glutathione reductase and 2-vinylpyridine. Analytical Biochemistry 106: 207-212.

Habig WH, Jakoby WB. 1981. Assays for differentiation of glutathione S-transferases. Methods in Enzymology 77: 398-405.

Habig WH, Pabst MJ, Jakoby WB. 1974. Glutathione S-transferases. The first enzymatic step in mercapturic acid formation. The Journal of Biological Chemistry 249: 7130-7139.

Hariyadi, Yanuwiadi B, Polii B, Soemarno. 2013. Phytoremediation of arsenic from geothermal power plant waste water using Monochoria vaginalis, Salvinia molesta and Colocasia esculenta. International Journal of Bioscience 3: 104-111.

Heath RL, Packer L. 1968. Photoperoxidation in isolated chloroplasts. I. Kinetics and stoichiometry of fatty acid peroxidation. Archives of Biochemistry and Biophysics 125: 189-198.

Hernández LE, Sobrino-Plata J, Montero-Palmero MB et al. 2015. Contribution of glutathione to the control of cellular redox homeostasis under toxic metal and metalloid stress. Journal of Experimental Botany 66: 2901-2911.

Hodges DM, DeLong JM, Forney CF, Prange RK. 1999. Improving the thiobarbituric acid reactive substances assay for estimating lipid peroxidation in plant tissues containing anthocyanin and other interfering compounds. Planta 207: 604-611.

Hossain MA, Piyatida P, silva JAT, Fujita M 2012. Molecular mechanism of heavy metal toxicity and tolerance in plants: Central role of glutathione in detoxification of reactive oxygen species and methylglyoxal and in heavy metal chelation. Journal of Botany doi:10.1155/2012/872875.

Jozefczak M, Keunen E, Schat H, et al. 2014. Differential response of Arabidopsis leaves and roots to cadmium: glutathione-related chelating capacity vs antioxidant capacity. Plant Physiology and Biochemistry 83: $1-9$.

Khang HV, Hatayama M, Inoue C. 2012. Arsenic accumulation by aquatic macrophyte coontail (Ceratophyllum demersum L.) exposed to arsenite, and the effect of iron on the uptake of arsenite and arsenate. Environmental and Experimental Botany 83: 47-52.

Leão GA, Oliveira JA, Farnese FS, Gusman GS, Felipe RT. 2014. Sulfur metabolism: different tolerances of two aquatic macrophytes exposed to arsenic. Ecotoxicology and Environmental Safety 105: 36-42.

Li Y, Dankher OP, Carreira L, Smith AP, Meagher RB 2006. The shoot-specific expression of $\Upsilon$-glutamylcysteine synthetase directs the long-distance transport of thiol-peptides to roots conferring tolerance to mercury and arsenic. Plant Physiology 14: 288-298. 


\section{Adinan Alves da Silva, Juraci Alves de Oliveira, Fernanda Vidal de Campos, Cleberson Ribeiro and Fernanda dos Santos Farnese}

Lindeman W. 1958. Observations on the behavior of phosphate compounds in Chlorella at the transition from dark to light. Proceedings of the II International Conference on the Peaceful Uses of Atomic Energy 24: 8-15.

Liu WJ, Wood BA, Raab A, McGrath SP, Zhao FJ, Feldmann J. 2010. Complexation of arsenite with phytochelatins reduces arsenite efflux and translocation from roots to shoots in Arabidopsis thaliana. Plant Physiology 152: 2211-2221.

Liu X, Zhang S, Whitworth RJ, Stuart JJ, Chen MS. 2015. Unbalanced activation of glutathione metabolic pathways suggests potential involvement in plant defense against the gall midge Mayetiola destructor in wheat. Scientific Reports. 5: 8092. doi:10.1038/ srep08092.

Marin AR, Pezeshki SR, Masscheleyn PH, Choi HS. 1993. Effect of dimethylarsenic acid (DMAA) on growth, tissue arsenic and photosynthesis in rice plants. Journal of Plant Nutrition 16: 865-880.

Meyer AJ, Hell R. 2005. Glutathione homeostasis and redox regulation by sulfhydryl groups. Photosynthesis Research 86: 435-457.

Miranda CV, Schwartsburd PB. 2016. Aquatic ferns from Viçosa (MG, Brazil): Salviniales (Filicopsida; Tracheophyta). Brazilian Journal of Botany 39: 935-942.

Mishra S, Jha AB, Dubey RS. 2011. Arsenite treatment induces oxidative stress, upregulates antioxidant system, and causes phytochelatin synthesis in rice seedlings. Protoplasma 248: 565-577.

Mishra S, Srivastava S, Tripathi RD, Trivedi PK. 2008. Thiol metabolism and antioxidant systems complement each other during arsenate detoxification in Ceratophyllum demersum L. Aquatic Toxicology 86: 205-215

Nagalakshmi N, Prasad MNV. 2001. Responses of glutathione cycle enzymes and glutathione metabolism to copper stress in Scenedesmus bijugatus. Plant Science 160: 291-299.

Naujokas MF, Anderson B, Ahsan H et al. 2013. The broad scope health effects fron chronic arsenic exposure: update on a worldwide public health problem. Environmental Health Perspectives 121: 295-302.

Nicomel NR, Leus K, Folens K, Voort PV, Du Laing GD. 2016. Technologies for arsenic removal from water: current status and future perspectives. International Journal of Environmental Research and Public Health 13: 62. doi:10.3390/ijerph13010062.

Noctor G, Mhamdi A, Chaouch S, et al. 2012. Glutathione in plants: an integrated overview. Plant Cell and Environment 35: 454-484.

Radotic K, Ducic T, Mutavdzic D. 2000. Changes in peroxidase activity and isoenzymes in spruce needles after exposure to different concentrations of cadmium. Environmental and Experimental Botany 44: 105-113.

Rahman MA, Hasegawa H. 2011. Aquatic arsenic: phytoremediation using floating macrophytes. Chemosphere 83: 633-646.

Rahman MA, Hasegawa H, Ueda K, Maki T, Rahman MM. 2008. Influence of phosphate and iron ions in selective uptake of arsenic species by water fern (Salvinia natans L.). Chemical Engineering Journal 145: 179-184.

Rai PK, Triphati BD. 2011. Heavy metal adsorption of a free floating aquatic macrophyte Spirodela polyrhiza. Journal of Environmental Research and Development 5: 656-660.

Rüegsegger A, Brunold CH. 1992. Effect of cadmium and/or removal of kernels or shoots on the levels of cysteine, $\Upsilon$-glutamylcysteine, glutathione, and TCA-soluble thiols in maize seedlings. Phyton 32: 109-112.

Seth CS, Remans T, Keunen E et al. 2012. Phytoextraction of toxic metals: a central role for glutathione. Plant Cell and Environment 35: 334-346.

Sharma I. 2012. Arsenic induced oxidative stress in plants. Biologia 67: $447-453$

Shen S, XF, Cullen WR, Weinfeld M, Le XC. 2013. Arsenic Binding to Proteins. Chemical Reviews 113: 7769-7792.

Shri M, Kumar S, Chakrabarty D, Trivedi PK et al. 2009. Effect of arsenic on growth, oxidative stress, and antioxidant system in rice seedlings. Ecotoxicology and Environmental Safety 72: 1102-1110

Singh HP, Batish DR, Kohali RK, Arora K. 2007. Arsenic-induced root growth inhibition in mung bean (Phaseolus aureus Roxb.) is due to oxidative stress resulting from enhanced lipid peroxidation. Plant Growth Regulation 53: 65-73.

Singh VP, Singh S, Kumar J, Prasad SM. 2015. Investigating the roles of ascorbate-glutathione cycle and thiol metabolism in arsenate tolerance in ridged Luffa seedlings. Protoplasma 252: 1217-29.

Srivastava M, Ma LQ, Singh N. 2005. Antioxidant responses of hyperaccumulator and sensitive fern species to arsenic. Journal of Experimental Botany 56: 335-1342.

Srivastava S, Mishra S, Tripathi RD, Dwivedi S, Trivedi PK, Tandon PK. 2007. Phytochelatins and antioxidant systems respond differentially during arsenite and arsenate stress in Hydrilla verticillata (L.f.) Royle. Environmental Science and Technology 4: 2930-2936.

Sytar O, Kumar A, Latowski D, Kuczynska P, Strzalka K, Prasad MNV. 2013. Heavy metal-induced oxidative damage, defense reactions, and detoxification mechanisms in plants. Acta Physiologia Plantarum 35: 985-999.

Talukdar D. 2013. Effect of arsenic-induced toxicity on morphological traits of Trigonella foenum-graecum L. and Lathyrus sativus L. during germination and early seedling growth. Current Research Journal of Biological Sciences 3: 116-123.

Tausz M, Pilch B, Rennenberg H, Grill D, Herschbach C. 2004. Root uptake, transport, and metabolism of externally applied glutathione in Phaseolus vulgaris seedlings. Journal of Plant Physiology 161: 347-9.

Tripathi P, Singh RP, Sharma YK, Tripathi RD. 2015. Arsenite stress variably stimulates pro-oxidant enzymes, anatomical deformities, photosynthetic pigment reduction and antioxidants in arsenic tolerant and sensitive rice seedlings. Environmental Toxicology and Chemistry 34: 1562-1571.

Upadhyaya H, Shome S, Roy D, Bhattacharya MK. 2014. Arsenic induced changes in growth and physiological responses in Vigna radiata seedling: effect of curcumin interaction. American Journal of Plant Sciences 5: 3609-3618.

Zagorchev L, Seal EC, Kranner I, Mariela Odjakova M. 2013. A central role for thiols in plant tolerance to abiotic stress. International Journal of Molecular Sciences 14: 7405-7432.

Zhang X, Uroic MK, Xie WY, et al. 2012. Phytochelatins play a key role in arsenic accumulation and tolerance in the aquatic macrophyte Wolffia globosa. Environmental Pollution 165: 18-24.

Zhao FJ, Ma JF, Meharg AA, McGrath SP. 2009. Arsenic uptake and metabolism in plants. New Phytologyst 181: 777-794.

Zhao FJ, McGrath SP, Meharg AA. 2010. Arsenic as a food chain contaminant: mechanisms of plant uptake and metabolism and mitigation strategies. Annual Review of Plant Biology 61: 535-559.

Zheng L, Liu Z, Yan Z, et al. 2017. Deriving water quality criteria for trivalent and pentavalent arsenic. Science of the Total Environment 587-588: 68-74. 